\title{
A quantitative analysis of modifier mutations which occur in mutation accumulation lines in Drosophila melanogaster
}

\author{
KO HARADA \\ Department of Biology, Faculty of Science, Kyushu University 33, Fukuoka 812, Japan
}

\begin{abstract}
Seven enzyme activities were measured in Drosophila melanogaster lines in which spontaneous mutations had accumulated over about 300 generations under the minimum pressure of natural selection. These enzymes included alcohol dehydrogenase (ADH), $\alpha$-glycerol-3-phosphate dehydrogenase $(\alpha \mathrm{GPDH})$, malate dehydrogenase $(\mathrm{MDH})$, isocitrate dehydrogenase (IDH), glucose-6-phosphate dehydrogenase (G6PD), 6-phosphogluconate dehydrogenase (6PGD) and $\alpha$-amylase (AMY). A significant genetic variance was observed for some enzyme activities. The mutations which alter the enzyme activities are called modifier mutations. The magnitudes of the genetic variance in modifier mutations differed greatly among enzymes but were often similar between two series of mutation accumulation lines (AW and JH). This may therefore indicate that the number of modifiers is specific for each enzyme system. The modifier mutation rate is suggested to be one of the clues for assessing the maintenance mechanism of protein polymorphism in natural populations.
\end{abstract}

Keywords: Drosophila melanogaster, enzyme activities, genetic variance, modifier mutations, mutation rates, protein polymorphism.

\section{Introduction}

In the past two decades a natural variation of enzyme activities has been reported in various organisms such as in Zea mays (Scandalios \& Baum, 1982), Mus musculus (Paigen, 1979) and especially in Drosophila (Ward \& Hebert, 1972; Choudhary \& Laurie, 1991; Laurie et al., 1991). These studies have shown that large variation in enzyme activities exists in natural populations. Mutations that affect enzyme activities are generally called modifiers and are considered to be quantitative characters (Laurie-Ahlberg et al., 1982). The candidates for such mutations may be the ones that occur in regulatory elements on DNA sequences or the genes encoding regulatory proteins such as transcription factors. The idea of co-ordinate expression of unlinked genes by common regulatory elements in eukaryotes, as first envisaged by the model of Britten \& Davidson (1969) is well established today (Ingham, 1988; Morimoto et al., 1990).

The potential importance of polymorphisms in such regulatory genes in natural populations as the source of adaptive evolution has been discussed (Wallace, 1963; King \& Wilson, 1975; Mukai \&
Cockerham, 1977; Hedrick \& McDonald, 1980). Therefore, in order to evaluate the evolutionary significance of regulatory genes it is important to determine the extent of the polymorphism in natural populations and to estimate how such genetic variation could accumulate in populations. The effect of regulatory mutations may be revealed in the genetic variation in the enzyme activities. In order to evaluate the accumulation rate of such mutations we have estimated the genetic variances in several enzyme activities using lines of Drosophila melanogaster in which spontaneous mutations have been accumulated for about 300 generations. It was shown that significant genetic variance arose in the enzyme activities of alcohol dehydrogenase (ADH: EC 1.1.1.1; map position, 2-50.1) (Mukai et al., 1984) $\alpha$-glycerol-3-phosphate dehydrogenase ( $\alpha \mathrm{GPDH}$ : EC 1.1.1.8, map position, 2-17.8) (Koga et al., 1992) and $\alpha$-amylase (AMY: EC 3.2.1.1; map position, 2-77.7) (Tachida et al., 1989). In this study I extend the screening to seven enzymes and analyse the relation among the enzyme activities. The additional enzymes are malate dehydrogenase (MDH: EC 1.1.1.37; map position, 2-37.2), isocitrate dehydrogenase (IDH: EC 1.1.1.42; map position, 3-27.1), 
glucose-6-phosphate dehydrogenase (G6PD: EC 1.1.1.49; map position, 1-63) and 6-phosphogluconate dehydrogenase (6PGD: EC 1.1.1.44; map position, 1-0.6). The results of the previous experiments mentioned above are also reanalysed here.

\section{Materials and methods}

\section{Establishment of lines}

One thousand second chromosome lines were established using four ancestral chromosomes: two balancer chromosomes, $\operatorname{In}(2 L R) S M 1$ marked by the dominant gene Curly (abbreviated as $C y$ ) and two lethal-carrying chromosomes $l(\mathrm{AW})$ and $l(\mathrm{JH})$, which were derived in 1967 from a cage population, $\mathrm{W}-1$. The lines were maintained by single-pair matings and accumulated spontaneous mutations until 1975. Subsequently the lines were maintained in a mass culture. The detailed method of mutation accumulation has been described elsewhere (Yamaguchi \& Mukai, 1974; Mukai \& Cockerham, 1977), and was developed at North Carolina State University by Mukai and his collaborators. In early 1980 , about 100 lines, 50 from the AW and 50 from the $\mathrm{JH}$ lines, were randomly chosen and transferred to Kyushu University. The genetic backgrounds (X, third and fourth chromosomes) of these lines were then substituted by repeated back-crosses to two kinds of balanced lethal stocks of C-160, that is $\operatorname{In}(2 L R) S M 1 / \operatorname{In}(2 L R) b w^{V 1}$, abbreviated as $C y / P m$. One was C-160(G37), which had the isogenic background of $\mathrm{W}-1$, and the other was $\mathrm{C}-160(\mathrm{~K})$, with the isogenic background of the Kaduna population (Clark et al., 1979). The former substitution lines were called $\mathrm{AW}(\mathrm{G})$ and $\mathrm{JH}(\mathrm{G})$, and the latter $\mathrm{AW}(\mathrm{K})$ and $\mathrm{JH}(\mathrm{K})$. The activity assays were performed using $\mathrm{AW}(\mathrm{G})$ and $\mathrm{JH}(\mathrm{G})$ lines for $\mathrm{ADH}$, $\alpha \mathrm{GPDH}, \mathrm{MDH}, \mathrm{G} 6 \mathrm{PD}, 6 \mathrm{PGD}$ and AMY. The activity assay of IDH was carried out using AW(K) and $\mathrm{JH}(\mathrm{K})$ lines. The original lines and the substituted lines (experimental lines) were maintained at $18^{\circ} \mathrm{C}$ in a mass culture. About 300 generations of accumulation of mutations had occurred in these lines before the present experiments were conducted.

\section{Experimental crosses}

The experimental crosses for enzyme activity assay were performed as follows: In each of the experiments, four vials of $5 \mathrm{Cy} / l_{i} \times 5 \mathrm{Cy} / l_{i}$ crosses were made for each line, where $i$ indicates the line number. They were divided into two groups with two vials for each line. The first group and the second group of each experiment were called sets 1 and 2, respectively. The newly emerged $F_{1}$ offspring from each vial were collected and aged for 4-6 days in a fresh vial. Then a sample of five male flies was collected in a plastic centrifuge tube and used for the activity measurement. Otherwise it was frozen at $-20^{\circ} \mathrm{C}$ or at $-80^{\circ} \mathrm{C}$ until used for the measurement. The activity measurements of the $\mathrm{AW}$ and $\mathrm{JH}$ lines were carried out independently. The measurements of different sets were undertaken on different days. The control lines were derived from a single male from one of the randomly chosen $\mathrm{AW}$ or $\mathrm{JH}$ experimental lines for each enzyme activity assay. Each was crossed with a female from a marked inversion of the C-160 stock which had the same genetic background as the experimental lines. A single pair of $C y$ phenotype male and female was established and was expanded to about the same number of experimental lines. The control crosses were performed at the same time as the experimental lines. Samples were then randomized within the sets for the activity assay.

\section{Measurement of enzyme activities}

A sample of five male flies was sonicated with 0.2 $\mathrm{mL}$ (for $\mathrm{ADH}, \alpha \mathrm{GPDH}, \mathrm{MDH}$ and $\mathrm{IDH}$ ) or $0.4 \mathrm{~mL}$ (for G6PD, 6PGD and AMY) of distilled water and centrifuged at $2054 \mathrm{~g}$ for $10 \mathrm{~min}$ at $4^{\circ} \mathrm{C}$. The supernatant was used for the activity assay. For the $\mathrm{NAD}^{+}$and $\mathrm{NADP}^{+}$dependent reactions, activities were measured by observing the absorbance change resulting from the reduction of $\mathrm{NAD}^{+}$to $\mathrm{NADH}$ (ADH and $\alpha \mathrm{GPDH})$ or NADP ${ }^{+}$to NADPH (IDH, G6PD and 6PGD), or resulting from the oxidation of NADH to $\mathrm{NAD}^{+}(\mathrm{MDH})$, at $340 \mathrm{~nm}$ by a spectrophotometer. The reaction was observed at an interval of $30 \mathrm{~s}$ for $2 \mathrm{~min}$ at $25^{\circ} \mathrm{C}$. The $\alpha$-amylase activity was measured by observing the chromatic change of DNSA (3,5-dinitrosalycilic acid reagent) resulting from the production of reducing sugars. This reaction was carried out at $25^{\circ} \mathrm{C}$. The assay mixtures were made as follows. $\mathrm{ADH}: 20 \mu \mathrm{L}$ of the sample solution was added to $2.6 \mathrm{~mL}$ of the reaction mixture of $2.3 \mathrm{mM} \mathrm{NAD}^{+}$and $0.14 \mathrm{M}$ isopropanol in $0.05 \mathrm{M}$ Tris- $\mathrm{HCl}$ buffer at $\mathrm{pH}$ 8.5. $\alpha \mathrm{GPDH}: 25 \mu \mathrm{L}$ of the sample solution was added to $2.5 \mathrm{~mL}$ of the reaction mixture of $4.2 \mathrm{mM} \mathrm{NAD}^{+}$and $16 \mathrm{~mm}$ glycerol-3-phosphate in glycine- $\mathrm{NaOH}$ buffer at $\mathrm{pH}$ 8.5. $\mathrm{MDH}$ : $25 \mu \mathrm{L}$ of the sample solution was added to $0.65 \mathrm{~mL}$ of the reaction mixture of $0.2 \mathrm{~mm}$ $\mathrm{NADH}$ and $0.33 \mathrm{~mm}$ oxaloacetate in $0.1 \mathrm{~m}$ Tris- $\mathrm{HCl}$ buffer at $\mathrm{pH}$ 7.5. IDH: $40 \mu \mathrm{L}$ of the sample solution 
was added to $0.8 \mathrm{~mL}$ of the reaction mixture of 0.8 mM NADP ${ }^{+}, 20 \mathrm{mM} \mathrm{MgCl}_{2}$ and $5.8 \mathrm{~mm}$ trisodium citrate in $0.1 \mathrm{M}$ Tris- $\mathrm{HCl}$ buffer at $\mathrm{pH}$ 8.5. G6PD: $50 \mu \mathrm{L}$ of the sample solution was added to $0.65 \mathrm{~mL}$ of the reaction mixture of $0.525 \mathrm{~mm} \mathrm{NADP}^{+}, 19 \mathrm{~mm}$ $\mathrm{MgCl}_{2}$ and $4.2 \mathrm{mM}$ glucose-6-phosphate in $0.2 \mathrm{M}$ Tris- $\mathrm{HCl}$ buffer at $\mathrm{pH}$ 8.5. 6PGD: $100 \mu \mathrm{L}$ of the sample solution was added to $0.6 \mathrm{~mL}$ of the reaction mixture of $1.4 \mathrm{~mm} \mathrm{NADP}{ }^{+}, 24.5 \mathrm{mM} \mathrm{MgCl}_{2}$ and 3.5 $\mathrm{mM}$ 6-phosphogluconate in $0.2 \mathrm{M}$ Tris- $\mathrm{HCl}$ buffer at $\mathrm{pH}$ 8.5. For $\alpha$-amylase, the substrate solution was prepared with 1 per cent soluble starch (MerckZulkovsky) and 0.05 per cent glucose in $0.1 \mathrm{M}$ Tris$\mathrm{HCl}$ buffer at $\mathrm{pH}$ 7.4. It was boiled for a short time, then cooled down. Fifty $\mu \mathrm{L}$ of sample solution was added to $1.05 \mathrm{~mL}$ of the substrate solution. Two reactions were initiated at a $10 \mathrm{~min}$ interval, and 10 min after the second reaction they were stopped by adding $3 \mathrm{~mL}$ of DNSA solution. The optical density (OD) at $550 \mathrm{~nm}$ was measured after $10 \mathrm{~min}$ of boiling. The difference in the OD of the two reactions was taken to be the activity. The total amount of soluble protein was measured by the Lowry method (Lowry et al., 1951). The unit enzyme activity is defined as the amount of the enzyme which consumes $1 \mu \mathrm{mol}$ of the substrate per minute. The 'specific activity' is defined as the unit activity per mg soluble protein.

\section{Electrophoresis}

The electrophoretic mobilities of the enzymes were determined in all of the experimental lines. Starch gel was used for the electrophoresis of $\mathrm{NAD}^{+}$and $\mathrm{NADP}^{+}$dependent enzymes. The electrophoresis of $\alpha$-amylase was carried out using acrylamide gel.

\section{Results}

\section{Electrophoresis}

Electrophoresis was performed using the corre- sponding lines of the activity assay. The results are shown in Table 1 . No altered electromorphs were found in any of the lines except one null mutant found in $\alpha \mathrm{GPDH}$ in $\mathrm{AW}(\mathrm{G})$ lines. This line was not used for the $\alpha \mathrm{GPDH}$ activity assay.

\section{Enzyme activity assays}

Two-way ANOVA was performed on the enzyme activity data. Two factors, sets and lines, are involved. Therefore, the sources of variation comprise the set effect, the line effect, the interaction between the sets and the lines and the sampling error. The genetic effect of mutation accumulation is represented in the differences between the lines. We therefore called the variance between the lines the 'genetic variance'. The results of the analysis for each enzyme activity assay are summarized in Table 2 and are as follows.

$A D H$ Four-day-old male flies were used for the activity assay. Control lines were derived from one of the $\mathrm{JH}(\mathrm{G})$ lines. A highly significant line effect occurred in both the $\mathrm{AW}(\mathrm{G})$ and $\mathrm{JH}(\mathrm{G})$ lines, but not in the control lines. The set effect was significant in both the experimental lines. The interaction was not significant in any of the experiments. This means that the experimental conditions well controlled regardless of any large differences between the sets.

$\alpha G P D H$ An activity assay was carried out using 5-day-old males for set 1 and using 6-day-old male flies for set 2 . The control lines were derived from one of the $\mathrm{JH}(\mathrm{G})$ lines. The line effect was significant at the 5 per cent level in both the $A W(G)$ and $\mathrm{JH}(\mathrm{G})$ lines but was not significant in the control lines. The set effect was highly significant in all the experiments. No significant interaction occurred in any of the experiments.

$M D H$ Four-day-old male flies were used for the

Table 1 Electrophoretic mobilities of the AW and JH experimental lines of Drosophila melanogaster

\begin{tabular}{lccccccc}
\hline Lines & ADH & $\alpha$ GPDH & MDH & IDH & G6PD & 6PGD & AMY \\
\hline AW & FF & FS & SS & SS & SS & FF & 1,6 \\
JH & FF & FS & SS & SS & SS & FF & 1 \\
\hline
\end{tabular}

Electrophoretic mobilities were examined in $\mathrm{AW}(\mathrm{G})$ and $\mathrm{JH}(\mathrm{G})$ lines for $\mathrm{ADH}$, $\alpha$ GPHD, MDH, G6PD, 6PGD and AMY.

Electrophoretic mobilities of IDH were examined in $\mathrm{AW}(\mathrm{K})$ and $\mathrm{JH}(\mathrm{K})$ lines. FF, FS and SS indicate the homozygotes with the $F$ allele, the heterozygotes with $F$ and $S$ alleles and the homozygote with the $S$ allele, respectively. 
activity assay. The control lines were derived from both the $A W(G)$ and $\mathrm{JH}(\mathrm{G})$ lines. The line effect was not significant in any of the experimental or control lines. The set effect was significant in both the $A W(G)$ and $A W$-control lines, but was not significant in the $\mathrm{JH}(\mathrm{G})$ and $\mathrm{JH}$-control lines. None of the interactions was significant.

IDH An activity assay was carried out using 4-dayold male flies for set 1 and 5-day-old male flies for set 2. The control lines were derived from both the $\mathrm{AW}(\mathrm{K})$ and $\mathrm{JH}(\mathrm{K})$ lines. The line effect was not significant in any of the experimental or control lines. The set effect was highly significant in the $\mathrm{JH}(\mathrm{K})$, JH-control and AW-control lines but not significant in the $\mathrm{AW}(\mathrm{K})$ line. No significant interaction was observed in any of the experiments.

G6PD and 6PGD Activity assays were performed using 4-day-old male flies. The control lines were derived from both the $\mathrm{AW}(\mathrm{G})$ and $\mathrm{JH}(\mathrm{G})$ lines. The same samples were used for the G6PD and 6PGD activity assays. For G6PD, the line effect was significant at the 5 per cent level in both the $\mathrm{AW}(\mathrm{G})$ and $\mathrm{JH}(\mathrm{G})$ lines but was not significant in the control lines. The set effect was highly significant in all of the lines. The interaction was not significant in any of the experiments. For 6PGD, the line effect was significant at the 5 per cent level in both the AW(G) and $\mathrm{JH}(\mathrm{G})$ lines but was not significant in the control lines. The set effect was highly significant in the $\mathrm{AW}(\mathrm{G})$ lines but not significant in the $\mathrm{JH}(\mathrm{G})$ and both the AW- and JH-control lines. No significant interaction was observed in any of the experiments.

$\alpha$-amylase An activity assay was undertaken using 4-day-old male flies. Control lines were derived from both the $A W(G)$ and $\mathrm{JH}(\mathrm{G})$ lines. Two sets of crosses were performed in two different media, starch (set 1) and normal corn meal (set 2). The line effect was significant at the 1 per cent level in the $\mathrm{AW}(\mathrm{G})$ lines and at the 5 per cent level in the $\mathrm{JH}(\mathrm{G})$ lines. None of the control lines showed any significant line effect. Set effect was highly significant in all the experiments and showed that the mean activity of the sets was significantly higher in the starch medium. No significant interaction was observed between the sets and the lines except in the JH-control lines. The ratio of $\alpha$-amylase activity in an inducible medium (starch) compared to that in a noninducible medium (corn meal) is defined as 'inducibility' (Yamazaki \& Matsuo, 1984). One-way ANOVA was applied for the analysis of inducibility. No significant line effect was observed concerning the inducibility in both the $\mathrm{AW}(\mathrm{G})\left(F_{29,30}=1.20\right)$ and $\mathrm{JH}(\mathrm{G})\left(F_{25,26}=0.75\right)$ lines. This shows that no appreciable genetic variation occurred in the inducibility in the mutation accumulation lines.

\section{Variance components analysis}

Genetic variance was estimated from the ANOVA tables as follows:

$\hat{\sigma}_{\mathrm{G}}^{2}=\frac{1}{4}\{\mathrm{MS}($ Line $)-\mathrm{MS}($ Set $\times$ Line $)\}$,

where MS(Line) and MS(Set $\times$ Line) are the mean squares of the lines and the interaction between the sets and the lines, respectively, and $\hat{\sigma}_{\mathrm{G}}^{2}$ is the estimate of the variance component for the lines. The standard errors of the genetic variances were calculated after Mukai (1978). These values were calculated for all the enzyme activities and are summarized with activity means in Tables 3 and 4 . In order to measure the relative magnitude of the genetic variance, the genetic variance to the error variance ratio, $R$, was calculated as follows:

Table 2 Summary of the significance tests in the two-way ANovas of the enzyme activities of Drosophila melanogaster

\begin{tabular}{|c|c|c|c|c|c|c|c|c|c|c|c|c|}
\hline \multirow[b]{2}{*}{ Enzyme } & \multicolumn{3}{|c|}{ AW-experimental } & \multicolumn{3}{|c|}{ AW-control } & \multicolumn{3}{|c|}{ JH-experimental } & \multicolumn{3}{|c|}{ JH-control } \\
\hline & Set & Line & Set $\times$ Line & Set & Line & Set $\times$ Line & Set & Line & Set $\times$ Line & Set & Line & Set $\times$ Line \\
\hline $\mathrm{ADH}$ & $* *$ & $* * *$ & NS & - & - & - & $* * *$ & $* * *$ & NS & $* * *$ & NS & NS \\
\hline$\alpha \mathrm{GPDH}$ & $* * *$ & $*$ & NS & - & - & - & $* * *$ & $*$ & NS & $* * *$ & NS & NS \\
\hline $\mathrm{MDH}$ & $* * *$ & NS & NS & $*$ & NS & NS & NS & NS & NS & NS & NS & NS \\
\hline IDH & NS & NS & NS & $* * *$ & NS & NS & $* * *$ & NS & NS & $* * *$ & NS & NS \\
\hline G6PD & $* * *$ & $*$ & NS & $* * *$ & NS & NS & $* * *$ & $*$ & NS & $* * *$ & NS & NS \\
\hline 6PGD & $* * *$ & $*$ & NS & NS & NS & NS & NS & $*$ & NS & NS & NS & NS \\
\hline AMY & $* * *$ & $* *$ & NS & $* * *$ & NS & NS & $* * *$ & $*$ & NS & $* * *$ & NS & $*$ \\
\hline
\end{tabular}

$F$-test: ${ }^{*} P<0.05,{ }^{* *} P<0.01,{ }^{* * *} P<0.005$.

NS, not significant. - Not available. 
Table 3 The enzyme activity means and genetic variance components in AW lines of Drosophila melanogaster

\begin{tabular}{lcccc}
\hline & & & & \\
Enzyme & No. of lines & Mean $(\mathrm{U} / \mathrm{mg})$ & $(\mathrm{U} / \mathrm{mg})^{2} \times 10^{-5}$ & $R$ \\
\hline Experimental & & & & \\
ADH & 37 & $0.242 \pm 0.023$ & $21.7 \pm 7.1$ & 0.780 \\
$\alpha$ GPDH & 31 & $0.305 \pm 0.031$ & $7.3 \pm 4.3$ & 0.242 \\
MDH & 29 & $0.986 \pm 0.137$ & $34.6 \pm 73.3$ & 0.033 \\
IDH & 31 & $0.0488 \pm 0.0057$ & $0.222 \pm 0.334$ & 0.083 \\
G6PD & 30 & $0.0215 \pm 0.0030$ & $0.189 \pm 0.098$ & 0.263 \\
6PGD & 30 & $0.00888 \pm 0.00184$ & $0.0725 \pm 0.0393$ & 0.302 \\
AMY & 30 & $0.260 \pm 0.066$ & $69.5 \pm 33.6$ & 0.304 \\
Control & & & & \\
ADH & - & - & - & - \\
$\alpha G P D H$ & - & - & $-137.4 \pm 167.6$ & 0.000 \\
MDH & 28 & $0.971 \pm 0.165$ & $-0.287 \pm 0.361$ & 0.000 \\
IDH & 25 & $0.0504 \pm 0.0064$ & $0.066 \pm 0.130$ & 0.064 \\
G6PD & 28 & $0.0255 \pm 0.0036$ & $-0.0267 \pm 0.0353$ & 0.000 \\
6PGD & 28 & $0.00990 \pm 0.00173$ & $-13.2 \pm 13.3$ & 0.000 \\
AMY & 16 & $0.171 \pm 0.054$ & - &
\end{tabular}

$R$ is considered to be zero when the genetic variance shows a negative value.

Table 4 The enzyme activity means and genetic variance components in JH lines of Drosophila melanogaster

\begin{tabular}{lcccc}
\hline & & & Genetic variance \\
Enzyme & No. of lines & Mean $(\mathrm{U} / \mathrm{mg})$ & $(\mathrm{U} / \mathrm{mg})^{2} \times 10^{-5}$ & $R$ \\
\hline Experimental & & & & \\
ADH & 32 & $0.317 \pm 0.035$ & $40.9 \pm 16.4$ & 0.708 \\
$\alpha$ GPDH & 39 & $0.286 \pm 0.027$ & $14.3 \pm 7.2$ & 0.258 \\
MDH & 25 & $1.090 \pm 0.261$ & $424 \pm 636$ & 0.059 \\
IDH & 25 & $0.0526 \pm 0.0079$ & $-0.039 \pm 0.550$ & 0.000 \\
G6PD & 27 & $0.0191 \pm 0.0032$ & $0.139 \pm 0.080$ & 0.183 \\
6PGD & 27 & $0.00869 \pm 0.00209$ & $0.0981 \pm 0.0550$ & 0.263 \\
AMY & 26 & $0.213 \pm 0.089$ & $154.9 \pm 88.1$ & 0.411 \\
Control & & & & \\
ADH & 20 & $0.302 \pm 0.037$ & $1.6 \pm 10.2$ & 0.012 \\
$\alpha G P D H$ & 21 & $0.203 \pm 0.160$ & $0.5 \pm 2.0$ & 0.021 \\
MDH & 27 & $1.007 \pm 0.2245$ & $34.9 \pm 399.5$ & 0.013 \\
IDH & 25 & $0.0504 \pm 0.0058$ & $-0.112 \pm 0.247$ & 0.000 \\
G6PD & 28 & $0.0159 \pm 0.0037$ & $0.054 \pm 0.104$ & 0.071 \\
6PGD & 28 & $0.00898 \pm 0.00209$ & $-0.0029 \pm 0.0294$ & 0.000 \\
AMY & 17 & $0.108 \pm 0.030$ & $-7.0 \pm 11.6$ & 0.000 \\
\hline
\end{tabular}

$R$ is considered to be zero when the genetic variance shows a negative value.

$R=\frac{\hat{\sigma}_{\mathrm{G}}^{2}}{\hat{\sigma}_{\mathrm{E}}^{2}}$,

where $\hat{\sigma}_{\mathrm{G}}^{2}$ and $\hat{\sigma}_{\mathrm{E}}^{2}$ are the estimates of the variance components of the lines and the errors, respectively.
$R$ was used for evaluating the magnitude of the genetic effect of modifier mutations between the different enzyme activities as well as between the AW and $\mathrm{JH}$ experimental lines. The value of $R$ for each experiment is also listed in Tables 3 and 4. Here, genetic variances which have negative values are 
considered to be zero. The values are ranged from $0.033(\mathrm{MDH})$ to $0.780(\mathrm{ADH})$ in the $\mathrm{AW}$ experimental lines, and from zero (IDH) to $0.708(\mathrm{ADH})$ in the $\mathrm{JH}$ experimental lines. The maximum increasing rate of the relative magnitude of the genetic variance was thus obtained in $\mathrm{ADH}$ activity and was 0.00260 and 0.00236 per second chromosome per generation for the $\mathrm{AW}$ and $\mathrm{JH}$ lines, respectively.

\section{Correlation in enzyme activities}

Many examples of the co-ordinate control of related genes by common regulatory factors have been shown by recent molecular studies. In order to test such co-ordinate expression of enzyme genes, correlations of enzyme activities were calculated for all of the pairwise comparisons. Phenotypic as well as genetic correlations were calculated. The genetic correlation $\left(r_{\mathrm{g}}\right)$ is calculated as follows:

$r_{\mathrm{g}}=\frac{\operatorname{Cov}\left(G, G^{\prime}\right)}{\sqrt{V(G) V\left(G^{\prime}\right)}}$,

where $\operatorname{Cov}\left(G, G^{\prime}\right)$ is the genetic covariance of two enzyme activities and $V(G)$ and $V\left(G^{\prime}\right)$ are the genetic variances of the respective enzyme activities. Standard errors of $r_{\mathrm{g}}$ were obtained by the method of Tallis (1959). The results are summarized in Tables 5 and 6 . In the AW lines, significant phenotypic correlations were obtained for the activities of $\mathrm{MDH}$ and 6PGD $(P<0.01)$ and G6PD and 6PGD $(P<0.01)$. The genetic correlation of the G6PD and 6PGD activities was apparently large, although not significant. In the $\mathrm{JH}$ lines, significant phenotypic correlations were obtained for the activities of ADH and $\mathrm{MDH}, \alpha \mathrm{GPDH}$ and IDH, $\alpha \mathrm{GPDH}$ and G6PD, and $\mathrm{MDH}$ and $\alpha$-amylase. All were significant at the 5 per cent level; however, none of the corresponding genetic correlations appeared to be significant. Among these phenotypically significant correlations three were negative and three positive.

The results obtained in the $\mathrm{AW}$ and $\mathrm{JH}$ lines were not consistent. A meaningful correlation was observed only for the activities of G6PD and 6PGD in the AW experimental lines. Using recently substituted lines, a highly significant positive correlation was observed in G6PD and 6PGD activities in both the AW and $\mathrm{JH}$ lines (K. Harada, unpublished results). A significant positive correlation in these enzyme activities has also been noted in natural populations (Bijlsma, 1980; Hori \& Tanda, 1981; Laurie-Ahlberg et al., 1981; Miyashita \& Laurie-Ahlberg, 1984). These two enzymes are closely related in the metabolic pathway of pentose phosphate

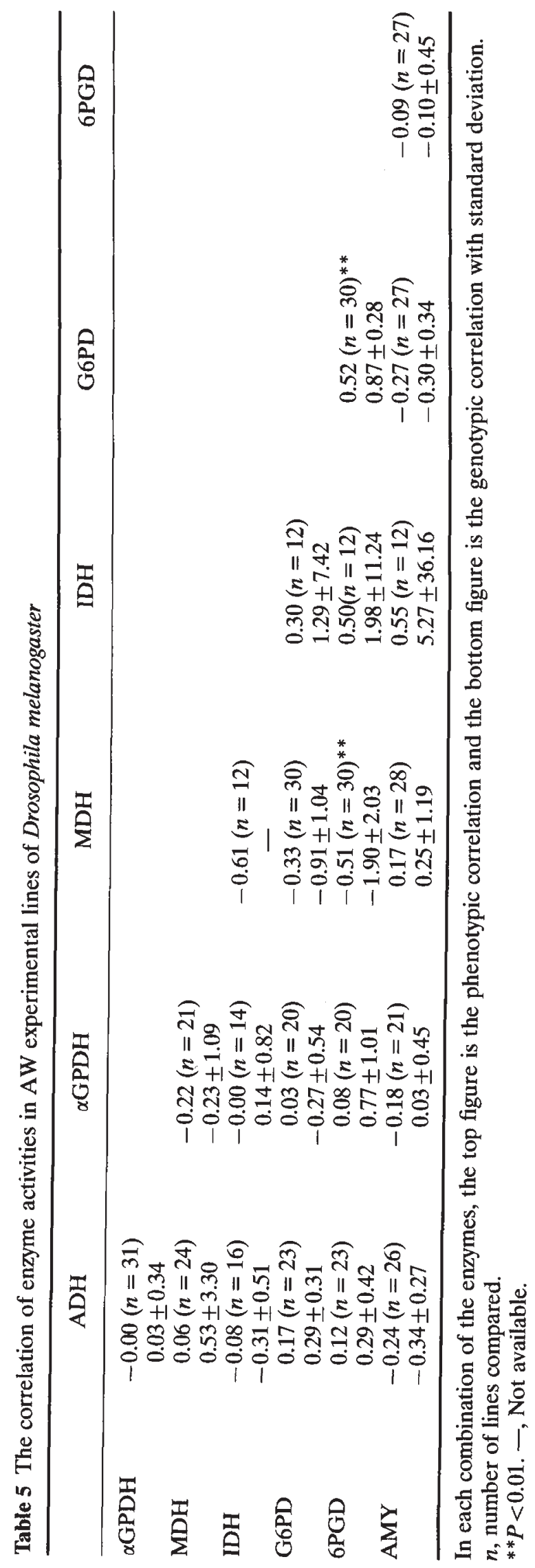

(c) The Genetical Society of Great Britain, Heredity, 75, 589-598. 




shunt. It is probable that some common factors are operating in the co-ordinate control of the expression of G6PD and 6PGD genes.

\section{Discussion}

A significant genetic variance occurred in some enzyme activities after the accumulation of mutations over about 300 generations. However, the magnitude is very different among enzymes. Significant variances apparently result from the mutations accumulated on the second chromosomes. Although mutations have been accumulated independently in the AW and JH lines, the results are in good agreement with each other. Accordance in the magnitudes of the genetic variance between the $\mathrm{AW}$ and $\mathrm{JH}$ lines was tested by Kendall's rank correlation coefficient, $\tau$, for $R$ in the $\mathrm{AW}$ and $\mathrm{JH}$ lines. $\tau=0.81$ $(n=7)$; the probability of $0.81(n=7)$; the probability of obtaining a higher value than this is less than 0.5 per cent indicating a highly significant association in the order between the $\mathrm{AW}$ and $\mathrm{JH}$ lines. The differential magnitude of the genetic variance may indicate that either the number of modifiers involved in each enzyme system is different or the modifier mutation rate is different among enzyme systems.

The probability that the structural genes of the enzymes acquired mutations during the accumulation of modifier mutations is calculated as follows. Band-morph and null mutation rates for enzyme loci were estimated in the AW and JH lines (Mukai \& Cockerham, 1977). They are $1.81 \times 10^{-6}$ and $10.3 \times 10^{-6} /$ locus/generation, respectively. Considering the detection rate for band-morph to be $1 / 3$ (Nei \& Chakraborty, 1973), the expected number of lines carrying at least one new mutation in a total of 60 lines is

$60 \times\left(1-\mathrm{e}^{-0.00000181 \times 3 \times 300 \times 2}\right)=0.195$.

Here, the null mutation rate is not considered because no nulls were used in this experiment. Because this is much less than one, the possibility that mutations of the structural gene affect the enzyme activity is ruled out. Aquadro et al. (1990) examined the restriction pattern of $15 \mathrm{~kb}$ regions including the ADH structural genes using 45 mutation accumulation lines of the $\mathrm{AW}$ and $\mathrm{JH}$ lines and found no major change in these regions. This observation suggests that the structural change of the $\mathrm{ADH}$ locus and flanking regions was not the source of activity variation. The same conclusion was derived from the survey of a $26 \mathrm{~kb}$ region surrounding the entire Gpdh gene (Koga et al., 1992).

(c) The Genetical Society of Great Britain, Heredity, 75, 589-598. 
Restriction site variation in the $14 \mathrm{~kb}$ region that includes the structural genes for $\alpha$-amylase was also investigated (Tachida et al., 1989). Contrary to the two enzymes mentioned above, it was found that most of the activity variation results from the substitution of the SM1 $(C y)$ chromosomal region by the corresponding regions of the lethal chromosomes. Gene conversion or double recombination was suggested to be a mechanism for this replacement. It is not known whether the occurrence of such events is specifically high in the $\alpha$-amylase coding region. The duplicated structure of the Amy gene (Gemmill et al., 1986) may contribute to this occurrence. The structural genes for G6PD, 6PGD and IDH are clearly not involved in the activity variation because the structural genes of these enzymes are located on the isogenic $X$ (G6PD and 6PGD) or the third (IDH) chromosomes. Thus, the main sources of the activity variation are suggested to exist in regions other than the enzyme coding regions.

In order to find a relationship between the modifiers and the parameters relating to population dynamics in natural populations, the correlation coefficient of $R$ with the average heterozygosity of the corresponding loci detected by electrophoresis was calculated. Significant positive correlations $(r=0.960$, d.f. $=4$ for AW, and $r=0.932$, d.f. $=4$ for $\mathrm{JH})$ were obtained using a data set collected over 18 species of Drosophila with a sample size of more than 60 (Gojobori, 1979). The $\alpha$-amylase locus was excluded from this analysis because the assay method is basically different from the other methods. When I used the heterozygosity data of only D. melanogaster alone (Singh \& Rhornberg, 1987), $r$ was 0.741 (d.f. $=4$ ) for the AW lines and $0.723(\mathrm{~d} . \mathrm{f}=4)$ for the $\mathrm{JH}$ lines. These values are not significant, but close to the 5 per cent level. In the past two decades many authors have attempted to establish a relationship between an enzyme function and its genetic variation in natural populations (Gillespie \& Kojima, 1968; Kojima et al., 1970; Gillespie \& Langley, 1974; Yamazaki \& Maruyama, 1974). It is generally considered that those enzymes showing a smaller amount of heterozygosity have stronger functional constraint than the enzymes showing a larger amount of heterozygosity. The former group of enzymes is often involved in the main single metabolic pathways and thus require a single physiological substrate. On the other hand, the latter group consists of the enzymes that are involved in multiple pathways or substrate-nonspecific enzymes (Gojobori, 1979). Our observations suggest that the latter group has a higher modifier mutation rate than the former group. The substantial entity of modifier mutations is totally unknown, but the mutations in the regions of regulatory function are the most probable candidates. Therefore, it is suggested that larger DNA regions are involved in the regulation of the gene expression in the latter group of enzymes. A consideration of the quantitative variations of the modifiers can thus be introduced as a new clue in the discussion of the maintenance mechanism of protein polymorphism in the context of the long-lasting debate of the neutralist-selectionist controversy. Because our data are restricted to modifiers on the second chromosomes and only a limited number of loci were examined, more extensive studies are required to obtain a general conclusion.

Finally, I must mention the role of transposable elements as the major agent of mutations. It has been suggested that many of the spontaneous visible mutations are caused by mobile genetic elements (Green, 1980; Spradling \& Rubin, 1981). Many examples of regulatory mutations caused by mobile elements have been reported in various organisms including yeast (Errede et al., 1980; Williamson et al., 1981), plants (Burr \& Burr, 1982; Döring et al., 1984), vertebrates (Hayward et al., 1981; Jenkins et al., 1981; Neel et al., 1981) and especially in Drosophila (Snyder et al., 1982; Bender et al., 1983; McGinnis et al., 1983; Scott \& Weiner, 1984; Tsubota et al., 1985; Zacher et al., 1985; Cote et al., 1986). Furthermore, some of the suppresser mutations which can modify gene expressions have been reported (Modolell et al., 1983; Mount et al., 1988; Geyer et al., 1991). Hence, it is possible that some of the activity mutations may be caused by mobile genetic elements. It was noticed that both the AW and $\mathrm{JH}$ lines carried active hobo and $I$ elements that are known to induce hybrid dysgenesis in certain matings (Harada et al., 1990). The number of these elements was very different among lines. It has been suggested that transposon mutagenesis is more efficient for the generation of regulatory mutations than EMS (Tsubota et al., 1985) because the cis-acting regulatory elements are relatively insensitive to single base pair changes (Eissenberg \& Elgin, 1987). Although there is no evidence for trans-acting regulatory factors, the above findings support the view that modifying mutations detected in this experiment largely result from the insertion of transposable elements.

\section{Acknowledgments}

I thank H. Tachida, Kyushu University for his careful reading of the manuscript and valuable com-

(c) The Genetical Society of Great Britain, Heredity, 75, 589-598. 
ments. I especially thank the late Professor T. Mukai who died on April 19, 1990 for his introduction to this problem and his continuous encouragement and helpful advice during the course of this work.

\section{References}

AQUADRO, C. F., TACHIDA, H., LANGLEY, C. H., HARADA, K. AND MUKAl, T. 1990. Increased variation in ADH enzyme activity in Drosophila mutation-accumulation experiment is not due to transposable elements at the Adh structural gene. Genetics, 126, 915-919.

BENDER, W., AKAM, M., KARCH, F., BEACHY, P. A., PElFER, M., SPIERER, P., LEWIS, E. B. AND HOGNESS, D. S. 1983. Molecular genetics of the bithorax complex in Drosophila melanogaster. Science, 221, 23-29.

BIJLSMA, R. 1980. Polymorphism at the G6pd and 6Pgd loci in Drosophila melanogaster. IV. Genetic factors modifying enzyme activity. Biochem. Genet., 18, 699-715.

BRITTEN, R. J. AND DAVIDSON, E. H. 1969. Gene regulation for higher cells. A theory. Science, 165, 349-357.

BURR, B. AND BURR, F. A. 1982. Ds controlling elements of maize at the shrunken locus are large and dissimilar insertions. Cell, 29, 977-986.

CHOUdhaRY, M. AND LAURIE, c. c. 1991. Use of in vitro mutagenesis to analyze the molecular basis of the difference in $A d h$ expression associated with the allozyme polymorphism in Drosophila melanogaster. Genetics, 129, 481-488.

CLARK, B., CAMFIELD, R. G., GALVIN, A. M. AND PITTS, C. R. 1979. Environmental factors affecting the quantity of alcohol dehydrogenase in Drosophila melanogaster. Nature, 280, 517-518.

COTE, B., BENDER, W., CURTIS, D. AND CHOVNIC, A. 1986. Molecular mapping of the rosy locus in Drosophila melanogaster. Genetics, 112, 769-783.

DÖRING, H.-P., FREELING, M., HAKE, S., JOHNS, M. A., KUNZE, R., MERCKELBACH, A., SALAMINI, S. AND STARLINGER, P. 1984. A $D s$-mutation of the Adh1-gene in Zea mays L. Mol. Gen. Genet., 193, 199-204.

eissenberg, J. C. AND Elgin, S. C. R. 1987. Hsp28stl : a Pelement insertion mutation that alters the expression of a heat shock gene in Drosophila melanogaster. Genetics, 115, 333-340.

ERREDE, B., CARDIllo, T. S., SHERMAN, F., DUBOIS, E., DESCHAMPS, J. AND WIAME, J. M. 1980. Mating signals control expression of mutations resulting from insertion of a transposable repetitive element adjacent to diverse yeast genes. Cell, 22, 427-436.

GEMMILL, R. M., SCHWARTZ, P. E. AND DOANE, w. w. 1986. Structural organization of the Amy locus in seven strains of Drosophila melanogaster. Nucl. Acids Res., 14, 5337-5352.

GEYER, P. K., CHIEN, A. J., CORCES, V. G. AND GREEN, M. M. 1991. Mutations in the $s u(s)$ gene affect RNA processing in Drosophila melanogaster. Proc. Natl. Acad. Sci. U.S.A., 88, 7116-7120.
GILlesP1E, נ. H. AND KoJIMA, K. 1968. The degree of polymorphisms in enzymes involved in energy production compared to that in nonspecific enzymes in two Drosophila ananassae populations. Proc. Natl. Acad. Sci. U.S.A., 61, 582-585.

GILlESPIE, J. H. AND LANGLEY, C. H. 1974. A general model to account for enzyme variation in natural populations. Genetics, 76, 837-848.

GOJOBOR1, T. 1979. Studies of protein polymorphism by data analysis with respect to loci. Ph. D. Thesis, Kyushu University, Fukuoka.

GREEN, M. M. 1980. Transposable elements in Drosophila and other diptera. Ann. Rev. Genet., 14, 109-120.

HARADA, K., YUKUHIRO, K. AND MUKAl, T. 1990. Transposition rates of movable genetic elements in Drosophila melanogaster. Proc. Natl. Acad. Sci. U.S.A., 87, 3248-3252.

HAYWARD, W. S., NEEL, B. G. AND ASTRIN, s. M. 1981. Activation of a cellular onc gene by promoter insertion in ALV-induced lymphoid leukosis. Nature, 290, 475-480.

HEDRICK, P. W. AND McDONALD, J. F. 1980. Regulatory gene adaptation: an evolutionary model. Heredity, 45, 83-97.

HORI, S. H. AND TANDA, s. 1981. Genetic variation in the activities of glucose 6-phosphate dehydrogenase and 6-phosphogluconate dehydrogenase in Drosophila melanogaster. Evidence for an autosomal modifier system. Jap. J. Genet., 56, 257-277.

INGHAM, P. W. 1988. The molecular genetics of embryonic pattern formation in Drosophila. Nature, 335, 25-34.

JENKINS, N. A., COPELAND, N. G., TAYLOR, B. A. AND LEE, B. K. 1981. Dilute $(d)$ coat colour mutation of DBA/2J mice is associated with the site of integration of an ecotropic MuLV genome. Nature, 293, 370-374.

KING, M. C. AND wILSON, A. C. 1975. Evolution at two levels in humans and chimpanzees. Science, 188, 107-116.

KOGA, A., HARADA, K., KUSAKABE, s. AND MUKAI, T. 1992. Spontaneous mutations affecting glycerol-3-phosphate dehydrogenase enzyme activity in Drosophila melanogaster. Jap. J. Genet., 67, 125-132.

KoJIMA, K., GILlESPIE, J. AND TOBARI, Y. N. 1970. A profile of Drosophila species' enzymes assayed by electrophoresis. I. Number of alleles, heterozygosities, and linkage disequilibrium in glucose-metabolizing systems and some other enzymes. Biochem. Genet., 4, 627-637.

LAURIE, C. C., BRIDGHAM, J. T. AND CHOUdHARY, M. 1991. Associations between DNA sequence variation and variation in expression of the $A d h$ gene in natural populations of Drosophila melanogaster. Genetics, 129, 489-499.

LAURIE-AHLBERG, C. C., WILLIAMSON, J. H., COCHRANE, B. J., WILTON, A. N. AND CHASLOW, F. I. 1981. Autosomal factors with correlated effects on the activities of the glucose-6-phosphate and 6-phosphogluconate dehydrogenase in Drosophila melanogaster. Genetics, 99, $127-150$.

LAURIE-AHLBERG, C. C., WILTON, A. N., CRUTISINGER, J. W. AND EMIGH, T. H. 1982. Naturally occurring enzyme activity variation in Drosophila melanogaster. I. Source of variation for 23 enzymes. Genetics, 102, 191-206. 
LOWRY, O. H., ROSEBROUGH, M. N. J., FARR, A. L. AND RANDALL, R. J. 1951. Protein measurement with the folin phenol reagent. J. Biol. Chem., 193, 265-275.

McGINNIS, W., SHERMOEN, A. W. AND BECKENDORF, S. K. 1983. A transposable element inserted just $5^{\prime}$ to a Drosophila glue protein gene alters gene expression and chromatin structure. Cell, 34, 75-84.

MIYASHITA, N. AND LAURIE-AHLBERG, C. C. 1984. Genetical analysis of chromosomal interaction effects on the activities of the glucose 6-phosphate and 6-phosphogluconate dehydrogenase in Drosophila melanogaster. Genetics, 106, 655-668.

MODOLELL, J., BENDER, W. AND MESELSON, M. 1983. Drosophila melanogaster mutations suppressible by the suppresser of Hairy-wing are insertions of a 7.3-kilobase mobile element. Proc. Natl. Acad. Sci. U.S.A., 80, 1678-1682.

MORIMOTO, R. I., TISIÈRES, A. AND GEORGOPOULOS, C. 1990. The stress response, function of the proteins, and perspectives. In: Morimoto, R. I., Tisières, A. and Georgopoulos, C. (eds) Stress Proteins in Biology and Medicine, pp. 1-36. Cold Spring Harbor Laboratory, Cold Spring Harbor, NY.

MOUNT, S. M., GREEN, M. M. AND RUBIN, G. M. 1988. Partial revertants of the transposable element-associated suppressible allele white apricot in Drosophila melanogaster: structures and responsiveness to genetic modifiers. Genetics, 118, 221-234.

MUKAI, T. 1978. Shudan Idengaku. Kodansha, Tokyo.

MUKAI, T. AND COCKERHAM, c. C. 1977. Spontaneous mutation rates at enzyme loci in Drosophila melanogaster. Proc. Natl. Acad. Sci. U.S.A., 74, 2514-2517.

MUKaI, T., harada, K. AND yoshimarU, H. 1984. Spontaneous mutations modifying the activity of alcohol dehydrogenase (ADH) in Drosophila melanogaster. Genetics, 106, 73-84.

NEEL, B., HAYWARD, W., ROBINSON, H., FANG, J. AND ASTRIN, s. 1981. Avian leukosis virus-induced tumors have common proviral integration sites and synthesize discreet new RNAs: oncongenesis by promoter insertion. Cell, 23, 323-334.

NEI, M. AND CHAKRABORTY, R. 1973. Genetic distance and electrophoretic identity of proteins between taxa. $J$. Mol. Evol., 2, 323-328.

PAIGEN, K. 1979. Acid hydrolysis as models of genetic control. Ann. Rev. Genet., 13, 417-466.

SCANDAlios, J. G. AND BAUM, J. A. 1982. Regulatory gene variation in higher plants. $A d v$. Genet., 21, 347-370.

SCOTT, M. P. AND WEINER, A. J. 1984. Structural relationships among genes that control development: sequence homology between the Antennapedia, Ultrabithorax, and fushi tarazu loci of Drosophila. Proc. Natl. Acad. Sci. U.S.A., 81, 4115-4119.

SINGH, R. S. AND RHORNBERG, L. R. 1987. A comprehensive study of genetic variation in natural populations of Drosophila melanogaster. II. Estimates of heterozygosity and patterns of geographic differentiation. Genetics, 117, 255-271.

SNYDER, M., KIMBERELL, D., HUNKAPILLER, M., HILL, R., ERISTROM, J. AND DAVIDSON, N. 1982. A transposable element which splits the promoter region inactivates a Drosophila cuticle protein gene. Proc. Natl. Acad. Sci. U.S.A., 79, 7430-7434.

SPRADLING, A. C. AND RUBIN, G. M. 1981. Drosophila genome organization: conserved and dynamic aspects. Ann. Rev. Genet., 15, 219-264.

TACHIDA, H., HARADA, K., LANGLEY, C. H., AQUADRO, C. F., YAMAZAKI, T. AND MUKAI, T. 1989. Restriction map and $\alpha$-amylase activity variation among Drosophila mutation accumulation lines. Genet. Res., 54, 197-203.

TALLIS, G. M. 1959. Sampling errors of genetic correlation coefficients calculated from analysis of variance and covariance. Aust. J. Stat., 1, 35-43.

TSubota, s., AShburner, M. AND schedl, P. 1985. P-element-induced control mutations at the $r$ gene of Drosophila melanogaster. Mol. Cell. Biol., 5, 2567-2574.

WALLACE, B. 1963. Genetic diversity, genetic uniformity and heterosis. Can. J. Genet. Cytol., 5, 239-253.

WARD, R. D. AND HEBERT, P. D. N. 1972. Variability of alcohol dehydrogenase activity in a natural population of Drosophila melanogaster. Nature New Biology, 236, 243-244.

WILlIAMSON, V. M., YOUNG, E. T. AND CIRIACY, M. 1981. Transposable elements associated with constitutive expression of yeast alcohol dehydrogenase II. Cell, 23, $605-614$.

YAMAGUCHI, O. AND MUKAI, T. 1974. Variation of spontaneous occurrence rates of chromosomal aberrations in the second chromosomes of Drosophila melanogaster. Genetics, 78, 1209-1221.

YAMAZAKI, T. AND MARUYAMA, T. 1974. Analysis of neutrality in protein polymorphism. Science, 183, 446-448.

YAMAZAKI, T. AND MATSUO, Y. 1984. Genetic analysis of natural populations of Drosophila melanogaster in Japan. III. Genetic variability of inducing factors of amylase and fitness. Genetics, 108, 223-235.

ZACHER, Z., DAVIDSON, D., GARZA, D. AND BINGHAM, P. M. 1985. A detailed developmental and structural study of the transcriptional effects of insertion of the copia transposon into the white locus of Drosophila melanogaster. Genetics, 111, 495-515. 